\title{
Analisa Kualitas Air Tukad Badung, Denpasar, Bali Menggunakan Program QUAL2Kw.
}

\author{
Richarta Vichotama $^{1 *}$, Riyanto Haribowo ${ }^{1}$, Tri Budi Prayogo ${ }^{1}$ \\ ${ }^{1}$ Jurusan Teknik Pengairan, Fakultas Teknik, Universitas Brawijaya \\ Jl. MT. Haryono No. 167, Malang, 65145, Indonesia \\ *Korespondensi Email: vichoricharta@gmail.com
}

\begin{abstract}
Tukad Badung River phisically has beauty and good. However, it has bad quality in this river. This study aims to determine the existing conditions of Tukad Badung water quality and determine the condition of the pollution capacity based on the analysis of the QUAL2Kw program. From the analysis, the water quality conditions in the study area showed that two of the eight parameters (Phosphate and BOD) did not comply the Class II of Quality Standards. Meanwhile, the Tukad Badung River's Pollution Capacity at TSS is 17.77 tons/day, at BOD 27.49 tons/day, at COD 93.63 tons/day, and on Phosphate 7.65 tons/day. In the prediction of water quality in Tukad Badung in 2024, there will be a decrease in water quality in the Tukad Badung river, this can be predicted from the decreasing trend of water quality calculated by the polynomial reduction graph. Some parameters are predicted not to meet class II quality standards, namely the parameters of BOD and Phosphate, the same as in previous years. BOD decreased by $-8.93 \%$ (BOD concentration increased by $8.93 \%$ ) and Phosphate decreased by $-16.67 \%$ (phosphate concentration increased by $16.67 \%)$
\end{abstract}

Keywords: Denpasar City River, QUAL2Kw, Tukad Badung, Water Quality

Abstrak: Sungai Tukad Badung secara fisik terbilang baik, namun memiliki kualitas air yang buruk. Penelitian ini bertujuan untuk mengetahui kondisi eksisting kualitas air Tukad Badung dan mengetahui kondisi daya tampung pencemaran berdasarkan analisa program QUAL2Kw. Dari hasil analisa, kondisi kualitas air pada daerah studi menunjukkan dua dari delapan parameter (Fosfat dan BOD) tidak memenuhi baku mutu kelas II. Sedangkan Daya Tampung Pencemaran sungai Tukad Badung pada TSS yakni 17,77 ton/hari, pada BOD 27,49 ton/hari, pada COD 93,63 ton/hari, dan pada Fosfat 7,65 ton/hari. Pada prediksi kualitas air Tukad Badung tahun 2024, terjadi penurunan kualitas air pada sungai Tukad Badung, hal ini dapat diprediksi dari trend penurunan kualitas air yang dihitung grafik penurunanya secara polinomial. Beberapa parameter diprediksi tidak memenuhi baku mutu kelas II yakni pada parameter BOD dan Fosfat, sama seperti pada tahun-tahun sebelumnya. BOD memiliki penurunan sebesar $-8,93 \%$ (konsentrasi BOD naik 8,93\%) dan Fosfat memiliki penurunan sebesar $-16,67 \%$ (konsentrasi fosfat naik 16,67\%).

Kata kunci: Kualitas Air, QUAL2Kw, Sungai Kota Denpasar, Tukad Badung 


\section{Pendahuluan}

Salah satu sungai terbesar yang melintas di Denpasar adalah Sungai Tukad Badung. Secara fisik, Tukad Badung memang terus berbenah selama dua tahun terakhir. Sejak 2017, sungai yang membelah Denpasar dari utara ke selatan ini ditata sehingga terlihat lebih indah yang berpusat di Jl. Gajahmada, Pusat Kota Denpasar. Tukad Badung yang semula seolah tak terurus, kini dibuatkan bantaran sungai dari beton di kanan kirinya. Ada pula tempat duduk berundak sebagai amphiteatre, atraksi air, dan kerlap-kerlip lampu saat malam hari. Dan kini, Tukad Badung menjadi daya tarik baru. Bahkan, beberapa orang menyebut Tukad Badung dengan istilah Tukad Korea. Sebutan ini mengacu pada Sungai Cheonggyecheon di Seoul, Korea Selatan.

Kepala UPT PSDG Unud I.G.P. Wirawan, Ketua UPT Pengembangan Sumber Daya Genetika (PSDG) Universitas Udayana Bali meneliti kualitas air pada sungai Tukad Badung. Indikatornya yakni pada ikan seluang (Rasbora sp.) atau nyalian dalam bahasa setempat. Ikan nyalian dulunya banyak ditemukan di sungai-sungai Bali. Akan tetapi, kini jumlah ikan nyalian makin sedikit dan sulit ditemukan. Kemungkinanya yakni terjadi perubahan ekosistem pada sungai yang menyebabkan efek samping pada biota di sungai, terutama pada biota yang menggunakan air sebagai sumber metabolisme dan bertahan hidup [1]. Dan berkurangnya populasi ikan nyalian menjadi salah satu indikator menurunnya kualitas lingkungan Tukad Badung. Penyebab pencemaran itu di antaranya adalah pestisida pertanian dan racun ikan di hulu serta logam berat di bagian hilir [2].

Perlu adanya penelitian lebih lanjut tentang kualitas sungai untuk menunjang treatment penanggulangan pencemaran sungai Tukad Badung untuk menentukan besaran limbah yang maksimal masuk ke dalam sungai Tukad Badung. Dan diperlukan penelitian lebih lanjut untuk menyimulasikan kualitas sungai Tukad Badung untuk diproyeksikan di tahun-tahun mendatang. Adapun tujuan dari studi ini adalah mengetahui kondisi eksisting kuaitas air Tukad Badung dan mengetahui kondisi daya tampung pencemaran berdasarkan analisa program QUAL2Kw. Sedangkan manfaat yang diharapkan dari adanya studi ini adalah untuk mengetahui kondisi eksisting kualitas air Tukad Badung, untuk mengetahui kondisi daya tampung pencemaran berdasarkan analisa program QUAL2Kw, dan juga untuk memprediksi kondisi kualitas air Tukad Badung di tahun 2024.

\section{Bahan dan Metode}

\subsection{Bahan}

\section{A. Wilayah Studi}

Secara geografis Denpasar terletak diantara $115^{\circ} 10^{\prime} 23^{\prime \prime}$ hingga $115^{\circ} 16^{\prime} 27^{\prime \prime}$ Bujur Timur (BT) dan $08^{\circ} 35^{\prime} 31^{\prime \prime}$ sampai 08 44' 49" Lintang Selatan (LS). Daerah Aliran Sungai Tukad Badung dilihat dari 3 titik pantau yang pertama pada bagian hulu yang berada pada Jembatan Jl. Gajah Mada, pada bagian tengah antara Jembatan Gajah Mada-Bendung Gerak Badung dan bagian hilir terletak pada Bendung Gerak Badung-Estuary Dam.

B. Data penelitian yang dibutuhkan

- Data peta wilayah Sungai Tukad Badung ruas Jembatan Jalan Gajah Mada, Bendung gerak Badung, dan Estuary DAM dari Badan Penelitian dan Pengembangan Provinsi Bali.

- Data debit Sungai Tukad Badung ruas Jembatan Jalan Gajah Mada, Bendung gerak Badung, dan Estuary Dam dari Balai Wilayah Sungai Bali - Penida.

- Data kualitas air sungai Tukad Badung ruas Jembatan Jalan Gajah Mada, Bendung gerak Badung, dan Estuary Dam dari DLH Provinsi Bali.

- Data-data Klimatologi berasal dari Balai Wilayah Sungai Bali - Penida. 
- Data-data yang terkait dengan kondisi lingkungan setempat yang diperoleh dari DLH Provinsi Bali.

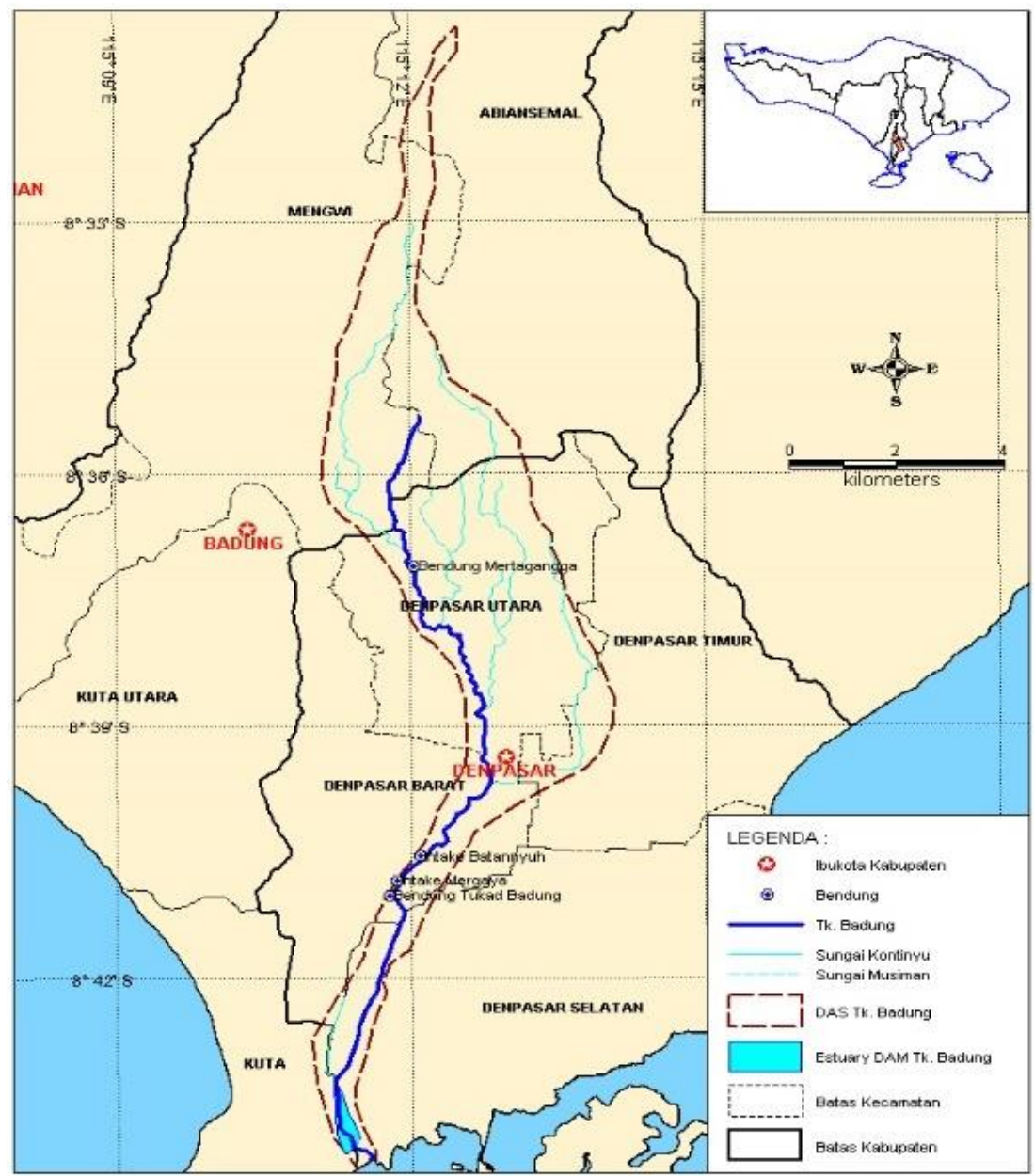

Gambar 1: Peta DAS Tukad Badung

Sumber: Balai Wilayah Sungai Bali-Penida, 2019

\subsection{Metode}

Pendekatan dalam studi ini menggunakan metode QUAL2Kw yang berupa pengembangan dari metode Q2E yang diskirp dengan bahasa program VBA "Visual Basic for Application" dengan interface dan input hingga hasil melalui Ms.Excel [3]. Data sekunder didapat dari Balai Wilayah Sungai (BWS) Bali - Penida yang berkaitan dengan model QUAL2Kw. Data primer diperoleh dari pengambilan sampel kemudian dilakukan uji laboratorium dan untuk setiap simulasi, hasilnya akan divalidasi dan kemudian dikalibrasi [4].

\section{Hasil dan Pembahasan}

\subsection{Pembagian Reach}

Reach 1 : Titik 1-Titik 2 (Rumah Sakit Umum Daerah Wangaya - Pasar Badung)

Reach 2 : Titik 2-Titik 3 (Pasar Badung - Jembatan Jalan Pulau Biak)

Reach 3 : Titik 3-Titik 4 (Jembatan Jalan Pulau Biak - Bank Victoria International) 
Reach 5 : Titik 4-Titik 5 (Bendung Gerak Badung - Waduk Muara Nusa Dua, Utara)

Reach 6 : Titik 5-Titik 6 (Waduk Muara Nusa Dua, Utara - Pura Waduk Muara)

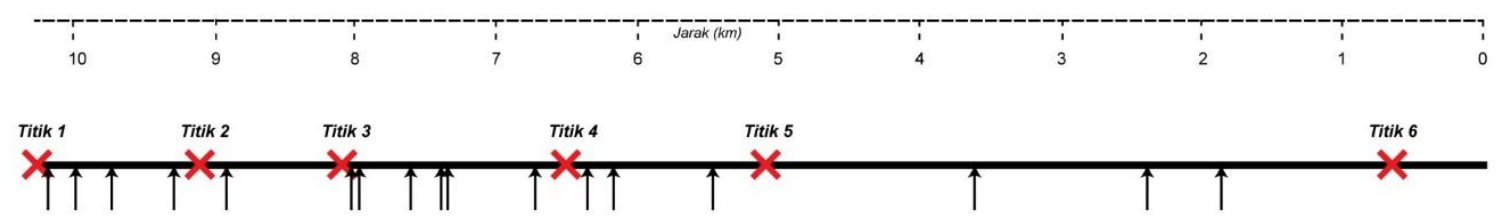

$\longrightarrow$ Titik Pantau
$\longrightarrow$ Point Source
$\longrightarrow$ Tukad Badung

Gambar 2: Skema Sungai Tukad Badung Besarta Point Source

\subsection{Kondisi Eksisting}

Hasil pemeriksaan Kualitas Air Tukad Badung pada titik pantau 1-6 didapatkan hasil yakni 2 dari 8 parameter tidak memenuhi baku mutu yakni pada Parameter BOD dan Fosfat.

Tabel 1: Hasil Pemeriksaan Kualitas Air Tk. Badung

\begin{tabular}{cccccccccc}
\hline \multirow{2}{*}{ No. } & \multirow{2}{*}{ Parameter } & \multirow{2}{*}{ Satuan } & Baku Mutu & \multicolumn{7}{c}{ Titik Pantau } \\
\cline { 5 - 9 } & & Kelas II & 1 & 2 & 3 & 4 & 5 & 6 \\
\hline 1 & Temperatur & $(\mathrm{C})$ & 30 & 27.2 & 27.2 & 27.3 & 27.2 & 27.5 & 27.8 \\
2 & pH & - & $6-7$ & 7.1 & 6.95 & 6.95 & 6.8 & 6.9 & 6.8 \\
3 & DO & $(\mathrm{mg} / \mathrm{l})$ & 4 & 6.2 & 6.2 & 6.15 & 6.25 & 6.2 & 5.3 \\
4 & COD & $(\mathrm{mg} / \mathrm{l})$ & 25 & 6.7 & 6.7 & 6.7 & 6.7 & 6.7 & 6.25 \\
5 & BOD & $(\mathrm{mg} / \mathrm{l})$ & 3 & 4.2 & 4.2 & 4.2 & 4.15 & 4.15 & 4.15 \\
6 & TSS & $(\mathrm{mg} / \mathrm{l})$ & 50 & 3.45 & 3.4 & 3.45 & 3.2 & 3.45 & 2.2 \\
7 & Fosfat & $(\mathrm{mg} / \mathrm{l})$ & 0.2 & 2.7 & 2.73 & 2.7 & 2.72 & 2.72 & 1.73 \\
8 & Total Coli & $(/ 100 \mathrm{ml})$ & 5000 & 2110 & 2110 & 2110 & 2110 & 2110 & 2120 \\
\hline
\end{tabular}

Tingginya kadar fosfat $\left(\mathrm{PO}_{4}\right)$ pada badan air diakibatkan banyaknya masukan limbah berupa detergen, limbah pertanian, dan juga veses. Fosfat menyebabkan blooming alga yang menyebabkan naiknya BOD dan turunya DO pada badan air [5]. Pada Tukad Badung, karena kadar fosfat naik, hal ini bisa jadi berpengaruh pada kenaikan BOD. Tingginya BOD diakibatkan banyaknya mikroorganisme dalam air yang membutuhkan oksigen untuk metabolisme organisme tersebut. Semakin tinggi BOD akan mengakibatkan kadar oksigen terlarut (DO) akan semakin kecil karena digunakan untuk metabolisme organisme biologis dalam air [6]. Bila dilihat pada pemeriksaan DO, nilainya masih masuk dalam kategori baku mutu kelas II, tapi nilainya tidak jauh diatas standar baku mutu kelas II [7].

\subsection{Kalibrasi Model}

Kalibrasi merupakan upaya untuk menyamakan data hasil buatan dengan data asli di lapangan [8]. Kalibrasi data dilakukan dengan memasukkan data-data sungai Tukad Badung ke dalam progam QUAL2Kw pada worksheet headwater, reach, dan data. Data kemudian dijalankan atau di-running dengan menjalankan "Run VBA" dan dilakukan trial and error pada worksheet rates untuk kalibrasi pada model agar model mendekati data. Dan pada nilai fitness didapatkan nilai sebesar 0,6514 sehingga dapat dilakuan perhitungan selanjutnya [9]. 


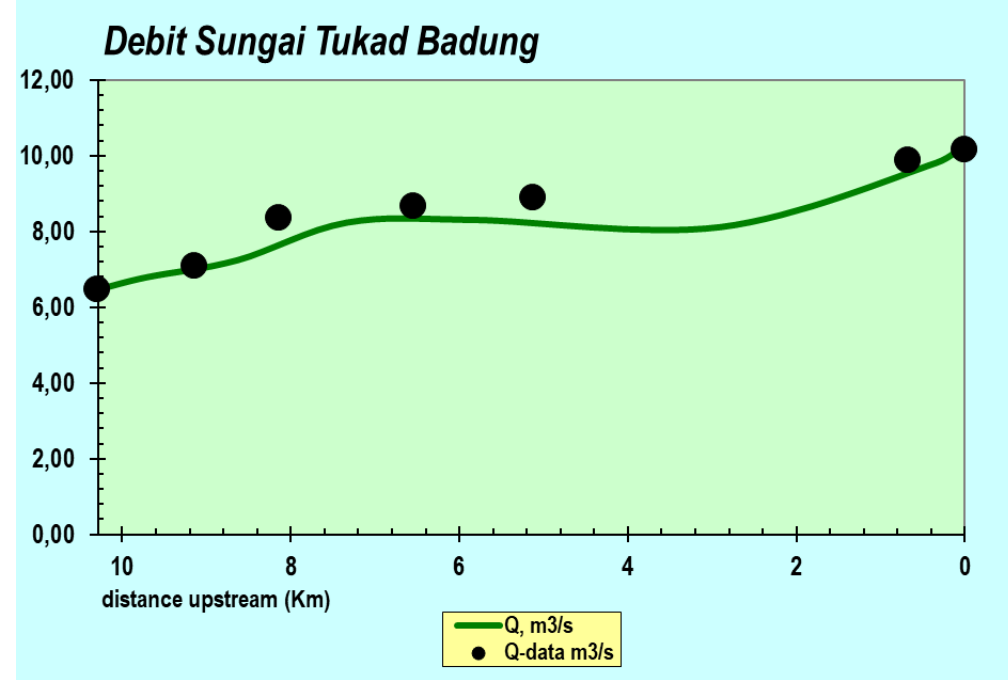

Gambar 3: Kalibrasi Model Debit

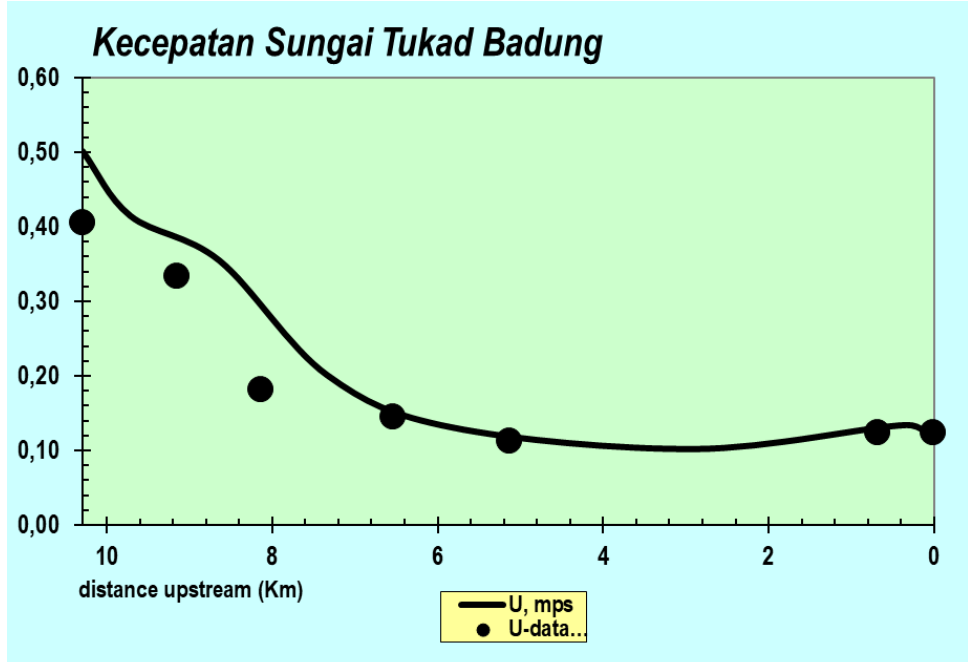

Gambar 4: Kalibrasi Model Kecepatan

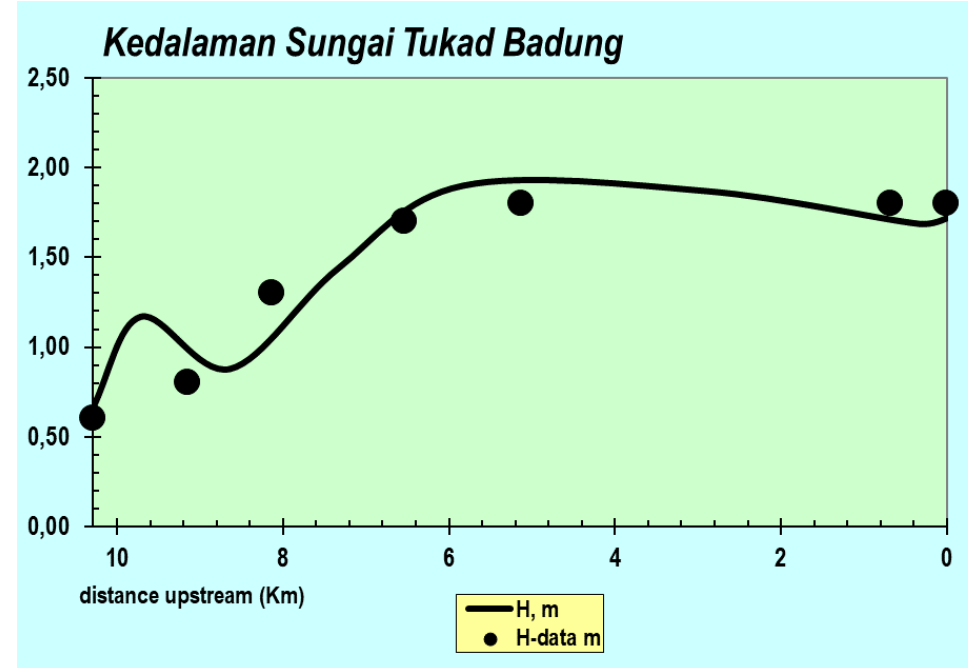

Gambar 5: Kalibrasi Model Kedalaman 


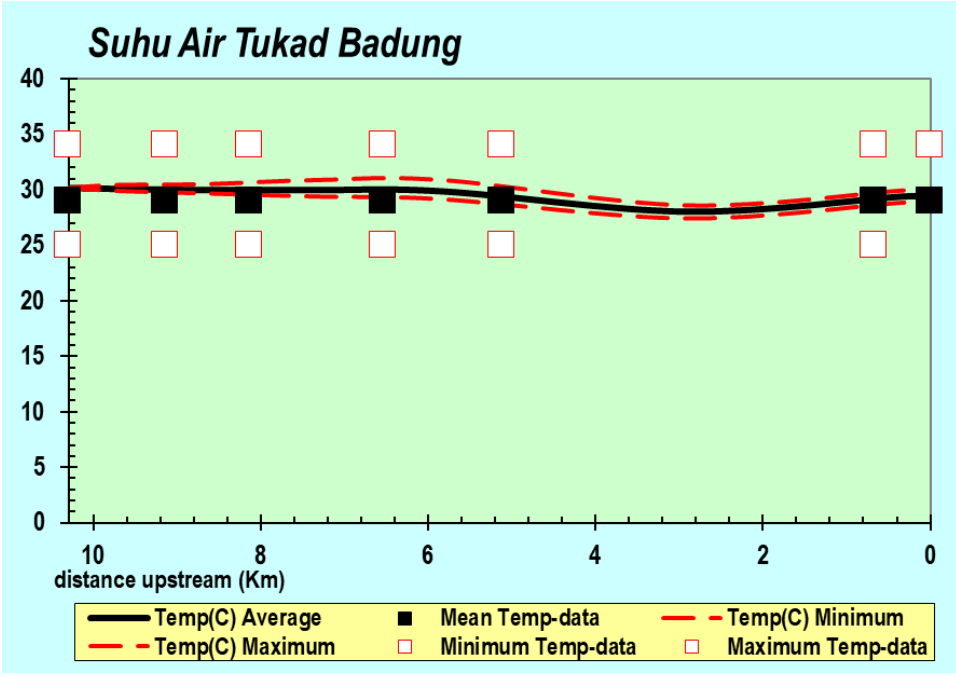

Gambar 6: Kalibrasi Model Suhu

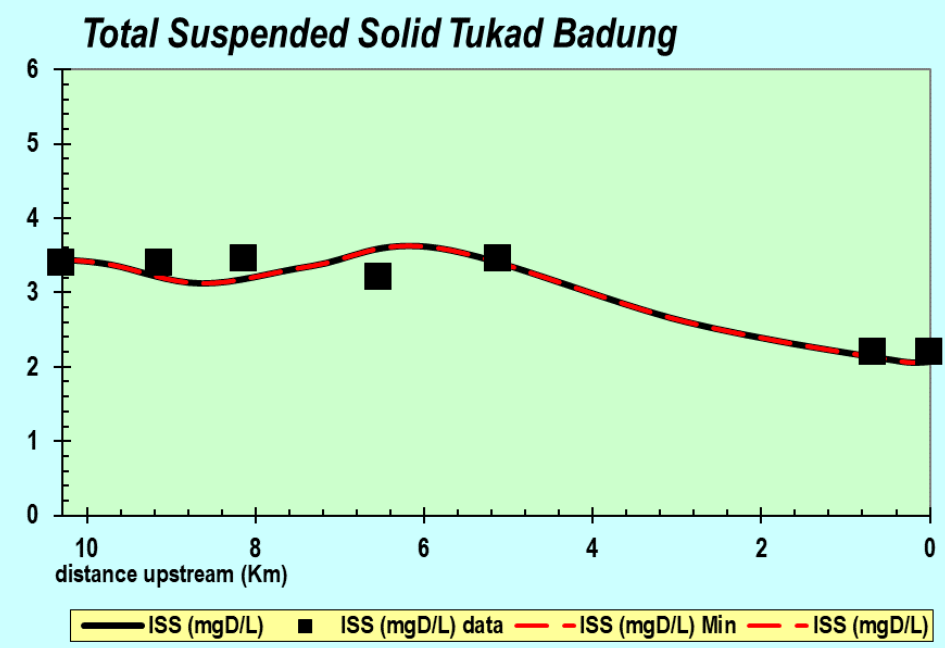

Gambar 7: Kalibrasi Model TSS

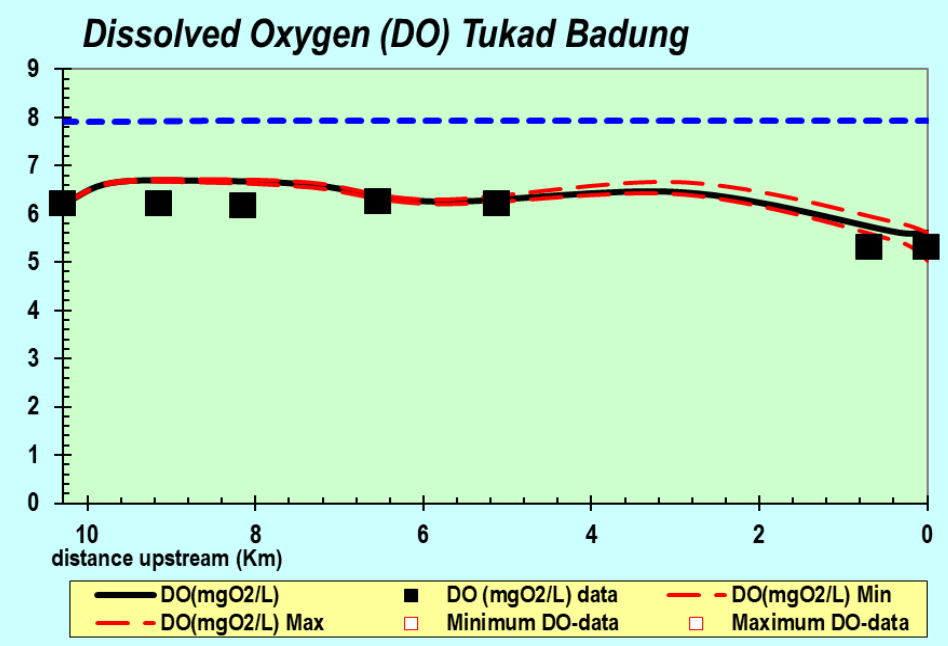

Gambar 8: Kalibrasi Model DO 


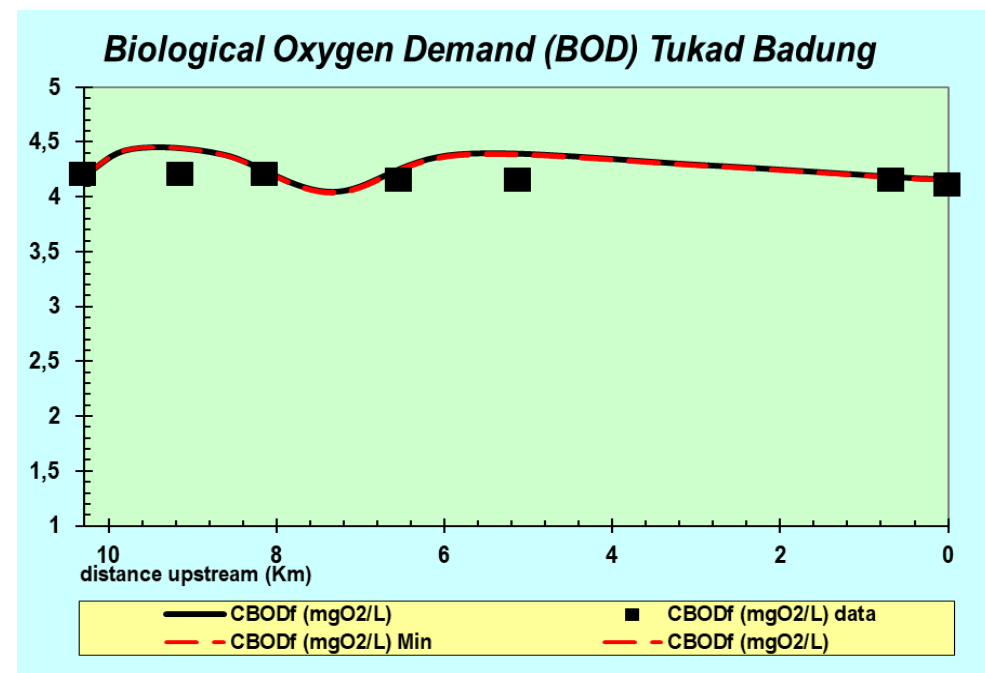

Gambar 9: Kalibrasi Model DO

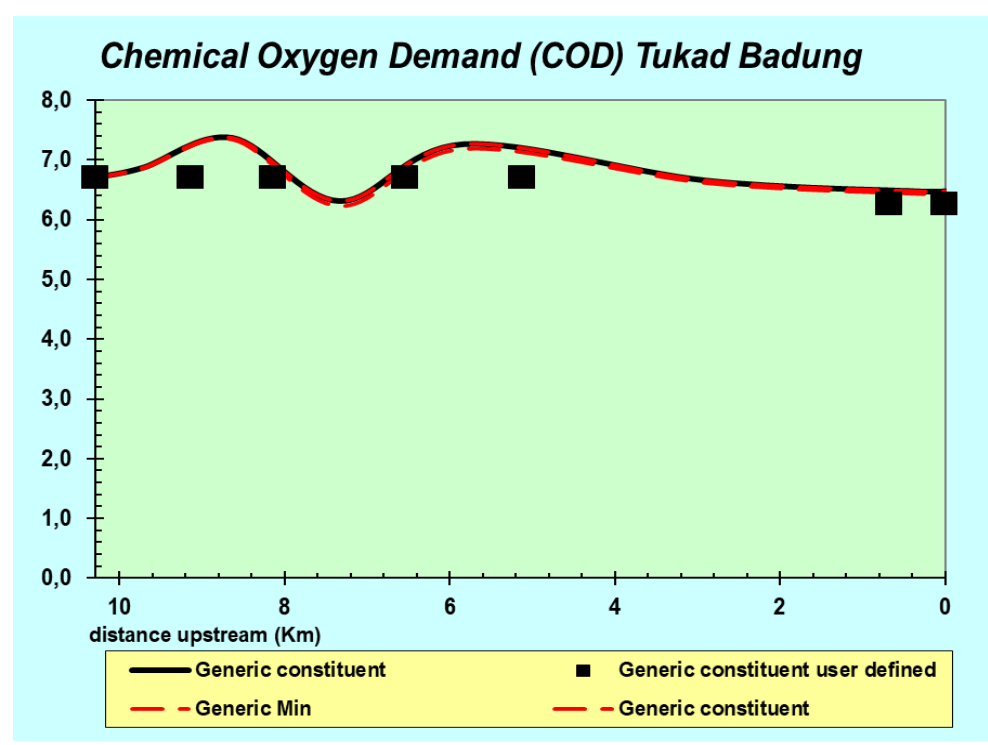

Gambar 10: Kalibrasi Model DO

\subsection{Validasi Model}

Validasi diperlukan agar data yang kita bangkitkan dapat dibandingkan dengan data asli pada lapangan [10]. Setelah dianalisa, validasi data pada masing-masing parameter yakni parameter Temperatur, pH, DO (Oksigen Terlarut), COD (Kebutuhan Kimia akan Oksigen), BOD (Kebutuhan Biologis akan Oksigen), TSS (Padatan Terlarut), Fosfat, dan Total Coliform pada Titik Pantau 1 hingga Titik Pantau 2 bisa dilihat nilainya cukup kecil dan memenuhi batas maksimal validasi data yakni memiliki kesalahan relatif dibawah $10 \%$. Sedangkan kesalahan relatif rerata model data yakni hanya 0,831 saja yang artinya dapat dilakukan perhitungan selanjutnya. Pada validasi yang sudah selesai, data bangkitan dianggap valid dan mewakili data-data historis beberapa tahun kebelakang [11]. 
Tabel 2: Validasi Model Bersdasarkan Trend 2 Tahun Data Terdahulu

\begin{tabular}{cccc}
\hline \multirow{2}{*}{ No. } & \multirow{2}{*}{ Titik } & \multicolumn{2}{c}{ Kesalahan Relatif } \\
& & Tahun 2018 & Tahun 2017 \\
\hline 1 & Titik Pantau 1 & 1.019 & 6.638 \\
2 & Titik Pantau 2 & 0.570 & 10.504 \\
3 & Titik Pantau 3 & 0.699 & 11.128 \\
4 & Titik Pantau 4 & 0.395 & 9.583 \\
5 & Titik Pantau 5 & 0.864 & 17.958 \\
6 & Titik Pantau 6 & 1.439 & 1.905 \\
\hline & Rerata & 0.831 & 9.619 \\
\hline
\end{tabular}

\subsection{Simulasi 1}

Simulasi 1 yakni merupakan skenario dimana tidak ada pencemaran baik point source maupun nonpoint source yang masuk pada sungai Tukad Badung. Bisa dilihat bahwa apabila tidak ada pencemar yang masuk ke dalam Tukad Badung, kondisi kualitas air bisa dikatakan baik karena telah memenuhi baku mutu kualitas air berdasarkan Peraturan Pemerintah RI No.82 th.2001.

Tabel 3: Simulasi 1

\begin{tabular}{cccccccc}
\hline \multirow{2}{*}{ Jarak $(\mathrm{km})$} & TSS & DO & BOD & Fosfat & Pathogen & COD & pH \\
\cline { 2 - 8 } & 50,00 & 4,00 & 3,00 & 0,20 & 5000,00 & 25,00 & 7,00 \\
10,29 & 36,11 & 5,02 & 2,99 & 0,16 & 4347,01 & 22,47 & 7,13 \\
9,71 & 21,91 & 5,57 & 2,72 & 0,14 & 3865,13 & 20,53 & 7,26 \\
8,64 & 19,70 & 5,84 & 2,41 & 0,09 & 3155,70 & 16,09 & 7,35 \\
7,34 & 12,05 & 6,01 & 2,32 & 0,05 & 2427,07 & 14,70 & 7,40 \\
5,83 & 4,65 & 7,44 & 1,55 & 0,01 & 1108,84 & 9,94 & 7,42 \\
2,9 & 3,70 & 6,38 & 1,49 & 0,01 & 1012,02 & 9,57 & 7,40 \\
0,34 & 3,70 & 6,38 & 1,49 & 0,01 & 1012,02 & 9,57 & 7,40 \\
0 & & & & & & &
\end{tabular}

\subsection{Simulasi 2}

Simulasi 2 di-running dengan memasukkan pencemar-pencemar yang masuk ke badan air. Bisa dilihat bahwa beberapa parameter memiliki kenaikan konsentrasi pencemar. Dan pada parameter Fosfat dan BOD memiliki konsentrasi yang melampaui standar baku mutu yang ditetapkan oleh Peraturan Pemerintah RI No.82 th.2001.

Tabel 4: Simulasi 2

\begin{tabular}{cccccccc}
\hline \multirow{2}{*}{ Jarak $(\mathrm{km})$} & TSS & DO & BOD & Fosfat & Pathogen & COD & pH \\
\cline { 2 - 7 } & 50,00 & 4,00 & 3,00 & 0,20 & 5000,00 & 25,00 & 7,00 \\
10,29 & 36,06 & 3,30 & 3,95 & 0,70 & 4577,70 & 23,17 & 7,13 \\
9,71 & 22,88 & 3,10 & 4,55 & 1,26 & 4424,50 & 22,03 & 7,23 \\
8,64 & 22,99 & 2,79 & 6,80 & 1,35 & 3615,08 & 20,84 & 7,28 \\
7,34 & 16,69 & 2,48 & 8,71 & 2,16 & 3240,73 & 21,84 & 7,26 \\
5,83 & 9,41 & 7,53 & 8,67 & 1,89 & 2755,54 & 18,88 & 7,44 \\
2,9 & 8,09 & 6,89 & 8,43 & 1,57 & 2598,57 & 18,38 & 7,40 \\
0,34 & 8,09 & 6,89 & 8,43 & 1,57 & 2598,57 & 18,38 & 7,40 \\
0 & & & & & &
\end{tabular}




\subsection{Simulasi 3}

Pada simulasi 3, parameter-parameter yang melampaui standar baku mutu pada simulasi sebelumnya diusahakan untuk dapat turun dan memenuhi standar baku mutu yang telah ditetapkan. Bisa dilihat pada hilir di setiap parameter memiliki konsentrasi yang memenuhi standar. Hal ini dapat dilakukan dengan cara melakukan percobaan trial-error pada sumber pencemar sehingga pada hilir dapat memenuhi standar baku mutu.

Tabel 5: Simulasi 3

\begin{tabular}{cccccccc}
\hline \multirow{2}{*}{ Jarak $(\mathrm{km})$} & TSS & DO & BOD & Fosfat & Pathogen & COD & pH \\
\cline { 2 - 8 } & 50,00 & 4,00 & 3,00 & 0,00 & 5000,00 & 25,00 & 7,00 \\
10,29 & 36,06 & 3,20 & 3,95 & 0,01 & 4577,70 & 23,17 & 7,13 \\
9,71 & 22,88 & 2,85 & 4,55 & 0,01 & 4424,50 & 22,03 & 7,23 \\
8,64 & 22,99 & 2,19 & 6,84 & 0,01 & 3615,08 & 20,84 & 7,28 \\
7,34 & 16,69 & 2,06 & 8,73 & 0,01 & 3240,73 & 21,84 & 7,26 \\
5,83 & 9,41 & 5,11 & 8,69 & 0,12 & 2755,54 & 18,88 & 7,44 \\
2,9 & 8,09 & 3,87 & 2,45 & 0,13 & 2598,57 & 18,38 & 7,40 \\
0,34 & 8,09 & 3,87 & 2,45 & 0,13 & 2598,57 & 18,38 & 7,40 \\
0 & & & & & & & \\
\hline
\end{tabular}

\subsection{Simulasi 4}

Di simulasi 4, data kondisi air di hulu menggunakan data sesuai dengan baku mutu dan pada bagian hilir diharapkan telah memenuhi baku mutu air kelas dua. Simulasi ini mengguanakan cara trial and error pada sumber pencemaran point source dan non-point source berupa limbah domestik dari rumah tangga dan hotel. Dapat dilihat bahwa terjadi kenaikan dan penurunan kualitas air, dan beberapa parameter melampaui standar baku mutu kualitas air seperti pada Fosfat dan BOD yang memiliki potensi besar untuk mencemari badan air. Jenis-jenis polutan banyak masuk pada simulasi ini, yang berasal dari Rumah Sakit, Pasar, dan Limbah domestik, yang menurut [12] hal ini harus diperhatikan karena sangat berpengaruh terhadap kualitas air pada hilir suatu sungai.

Tabel 6: Simulasi 4

\begin{tabular}{cccccccc}
\hline \multirow{2}{*}{ Jarak $(\mathrm{km})$} & \multicolumn{7}{c}{ Parameter } \\
\cline { 2 - 8 } & TSS & DO & BOD & Fosfat & Pathogen & COD & pH \\
\hline 10,29 & 2,22 & 5,78 & 3,83 & 2,25 & 2200,10 & 7,45 & 7,11 \\
9,71 & 2,52 & 6,33 & 4,08 & 2,44 & 1676,67 & 10,89 & 7,22 \\
8,64 & 2,61 & 6,64 & 4,43 & 2,76 & 1380,15 & 15,01 & 7,32 \\
7,34 & 2,90 & 7,29 & 4,87 & 2,53 & 1114,76 & 16,60 & 7,55 \\
5,83 & 3,32 & 7,18 & 6,57 & 3,04 & 822,93 & 20,85 & 7,65 \\
2,9 & 2,54 & 8,17 & 8,72 & 2,25 & 262,95 & 24,07 & 8,50 \\
0,34 & 2,02 & 7,69 & 8,43 & 1,81 & 205,51 & 24,93 & 7,99 \\
0 & 2,02 & 7,69 & 8,43 & 1,81 & 205,51 & 24,93 & 7,99 \\
\hline
\end{tabular}


3.9 Beban Pencemaran dan Daya Tampung Pencemaran

Tabel 7: Beban Pencemaran Minimal (Kg/Hari)

\begin{tabular}{ccccc}
\hline Jarak $(\mathrm{km})$ & TSS & BOD & COD & Fosfat \\
\hline 10,291 & 27907,2 & 1674,4 & 13953,6 & 111,6 \\
9,7145 & 21081,4 & 1743,0 & 13118,9 & 96,1 \\
8,636 & 13591,1 & 1685,8 & 12733,9 & 83,9 \\
7,336 & 12484,3 & 1526,3 & 10195,8 & 55,0 \\
5,8295 & 8288,9 & 1596,5 & 10111,4 & 33,0 \\
2,8985 & 3869,6 & 1291,4 & 8271,4 & 7,8 \\
0,338 & 3313,3 & 1337,4 & 8577,2 & 6,3 \\
0 & 3323,9 & 1341,7 & 8604,8 & 6,3 \\
\hline
\end{tabular}

Tabel 8: Beban Pencemaran Maksimal (Kg/Hari)

\begin{tabular}{ccccc}
\hline Jarak $(\mathrm{km})$ & TSS & BOD & COD & Fosfat \\
\hline 10,291 & 27907,20 & 1674,43 & 13953,60 & 111,63 \\
9,7145 & 21054,30 & 2305,08 & 13529,37 & 407,24 \\
8,636 & 14191,81 & 2819,80 & 13663,91 & 784,68 \\
7,336 & 14570,02 & 4308,57 & 13203,58 & 857,00 \\
5,8295 & 11481,28 & 5987,84 & 15020,09 & 1485,80 \\
2,8985 & 7830,45 & 7216,62 & 15721,10 & 1571,87 \\
0,338 & 7254,04 & 7554,92 & 16482,37 & 1411,45 \\
0 & 7277,39 & 7579,24 & 16535,42 & 1416,00 \\
\hline
\end{tabular}

Beban pencemaran merupakan besaran total beban jumlah suatu polutan yang mencemari satu badan air yang dinyatakan dalam kilogram polutan per hari [13]. Sumber pencemar kualitas air Tukad Badung berasal dari beberapa jenis limbah antara lain dari industri, pasar, rumah sakit, serta limbah domestik dari rumah tangga masyarakat. Tercatatat sebanyak 393 industri tekstil siap jadi, 129 pabrik batik, 663 industri kain, 393 industri sablon dan percetakan, 132 industri tahu dan tempe, serta 158 industri logam dari Dauh Puri Kangin hingga Waduk Muara yang membuang limbah ke Tukad Badung dengan total buangan produksi sebesar 243.491,39 m3 perharinya.

Tabel 9: Daya Tampung Pencemaran (Kg/Hari)

\begin{tabular}{ccccc}
\hline Jarak $(\mathrm{km})$ & TSS & BOD & COD & Fosfat \\
\hline 10,291 & 0,0 & 0,0 & 0,0 & 0,0 \\
9,7145 & 27,1 & 562,0 & 11786,3 & 311,1 \\
8,636 & 600,8 & 1134,0 & 11978,1 & 700,8 \\
7,336 & 2085,7 & 2782,3 & 11677,3 & 802,0 \\
5,8295 & 3192,4 & 4391,4 & 13423,6 & 1452,8 \\
2,8985 & 3960,8 & 5925,3 & 14429,7 & 1564,1 \\
0,338 & 3940,8 & 6217,5 & 15144,9 & 1405,1 \\
0 & 3953,4 & 6237,5 & 15193,7 & 1409,7 \\
\hline Total & 17706,8 & 27249,9 & 93633,6 & 7645,5 \\
\hline
\end{tabular}




\section{Kesimpulam}

Kondisi Eksisting hasil pemeriksaan Kualitas Air Tukad Badung pada titik pantau 1-6 didapatkan hasil yakni kualitas air Tukad Badung 2019 sebanyak 75\% parameter yang diuji memenuhi baku mutu kualitas air kelas II. 6 dari 8 parameter pemeriksaan kualitas air memenuhi standar baku mutu kelas II, dan 2 dari 8 parameter tidak memenuhi baku mutu yakni pada Parameter BOD dan Fosfat. Hal ini terjadi rata di seluruh titik pemeriksaan, yakni BOD dan Fosfat menjadi pencemar utama Tukad Badung pada eksisting tahun 2019.

Kondisi Kualitas Air di Sungai Tukad Badung pada beberapa parameter masih belum memenuhi Baku Mutu yang telah ditetapkan oleh Pemerintah pada PP Republik Indonesia Nomor 82 Tahun 2001 tentang pengelolaan Kualitas Air dan Pengendalian Pencemaran Air. Terhitung Daya Tampung Beban Pencemaran pada TSS yakni 17,77 ton/hari, pada BOD 27,49 ton/hari, pada COD 93,63 ton/hari, dan pada Fosfat 7,65 ton/hari.

Pada prediksi kualitas air Tukad Badung tahun 2024, terjadi penurunan kualitas air pada sungai Tukad Badung, hal ini dapat diprediksi dari trend penurunan kualitas air yang dihitung grafik penurunanya secara polinomial. Beberapa parameter diprediksi tidak memenuhi baku mutu kelas II yakni pada parameter BOD dan Fosfat, sama seperti pada tahun-tahun sebelumnya. BOD memiliki penurunan sebesar -8,93\% (konsentrasi BOD naik 8,93\%) dan Fosfat memiliki penurunan sebesar $16,67 \%$ (konsentrasi fosfat naik 16,67\%).

\section{Daftar Pustaka}

[1] Fajar, J., "Tukad Badung, Keindahan yang Menyamarkan Pencemaran yang Sesungguhnya", Mongabay, 7 Juni 2019, [Online], Tersedia : https://mongabay.co.id/2019/06/07/tukad-badungkeindahan-yang-menyamarkan-pencemaran-sesungguhnya/ [diakses 25 November 2019].

[2] Effendi, H., Telaah Kualitas Air, Bagi Pengelolaan Sumberdaya dan Lingkungan Perairan. Yogyakarta: Kanisius, 2003.

[3] H. Lestari, R. Haribowo, E. Yuliani., "Determination of Pollution Load Capacity Using QUAL2Kw Program on The Musi River Palembang," Civil and Environmental Science Journal 2 (2), 105-116, 2019.

[4] Kannel, S. Lee, YS. Lee, Palletier., Application of Automated QUAL2Kw for Water Quality Modelling and Management in The Bagmati River. Nepal. Ecol. Modell. 34(202):503-5 I 7), 2007

[5] Irianto, G., Pengelolaan Sumberdaya Lahan \& Air. Strategi Pendekatan dan Pendayagunaannya. Jakarta: Papas Sinar Sinanti, 2006.

[6] Mahasri M, S. Amin, A. Manan., Manajemen Kualitas Air. Surabaya: Global Persada Press, 2013.

[7] Salmin., "Oksigen Terlarut (DO) dan Kebutuhan Oksigen Biologi (BOD) Sebagai Salah Satu Indikator Untuk Menentukan Kualitas Perairan," Oseana, vol. XXX, no. 3, 2005:21-26. ISSN $02161877,2005$.

[8] Kordi, K Ghufron dan Andi, B Tancung., Pengelolaan Kualitas Air dalam Budidaya Perairan. Jakarta: Rineka Cipta, 2009.

[9] Mackereth, J. Heron, J.F. Talling., Water Analysis. Freshwater Biological Association, UK: Cambria, 1989. 
[10] R Haribowo, M. Yoshimura, M. Sekine, T. Imai, K. Yamamoto, T. Higuchi, A. Kanno., "Behavior of Toxicity in River Basins Dominated by Residential Areas," Contemporary Engineering Sciences, vol.10, no.7, pp 305-315, 2017.

[11] Metcalf, Eddy., Wastewater Engineering: Treatment and Resource Recovery. New York: McGraw - Hill Education, 2013.

[12] RW. Sayekti, R. Haribowo, Y. Vivit, dan A. Prabowo., "Studi Efektifitas Penurunan Kadar BOD, COD dan $\mathrm{NH}_{3}$ pada Limbah Cair Rumah Sakit dengan Rotating Biological Contactor," Jurnal Teknik Pengairan: Journal of Water Resources Engineering, vol.2, no.2, pp.182-189, 2011.

[13] Sugiharto., Dasar-dasar Pengolahan Air Limbah. Jakarta: Universitas Indonesia, 2005. 